\title{
Exogenous Urocortin 1 Alters the Respiratory Exchange Ratio after Administration into the Lateral Septum
}

\author{
Anna I. Fimmel, Lindsey M. Dono, Matthew N. Yee, Paul J. Currie* \\ Department of Psychology, Reed College, Portland, USA \\ Email: *pcurrie@reed.edu
}

Received January 6, 2014; revised February 5, 2014; accepted February 12, 2014

Copyright (C) 2014 Anna I. Fimmel et al. This is an open access article distributed under the Creative Commons Attribution License, which permits unrestricted use, distribution, and reproduction in any medium, provided the original work is properly cited. In accordance of the Creative Commons Attribution License all Copyrights (C) 2014 are reserved for SCIRP and the owner of the intellectual property Anna I. Fimmel et al. All Copyright @ 2014 are guarded by law and by SCIRP as a guardian.

\begin{abstract}
Previous reports have suggested that hypothalamic urocortin 1 (Ucn1) exerts inhibitory control on energy metabolism as direct paraventricular nucleus injections dose-dependently decrease the respiratory energy exchange ratio (RER). Other evidence indicates that Ucn1 injections into the lateral septum may alter metabolic function. Consequently, the present study was designed to further characterize the effects of lateral septal Ucn1 signaling on eating and energy metabolism of adult Sprague-Dawley rats. Ucn1 was infused at the onset of the nocturnal cycle at doses of 10 - $100 \mathrm{pmol}$. In both females and males the peptide elicited a reliable suppression of food intake and significantly lowered RER over a $4 \mathrm{~h}$ postinjection period. The decrease in RER is consistent with enhanced lipid oxidation. Overall these findings suggest that, similar to the paraventricular nucleus, the lateral septum is a critical site of action in mediating the effects of Ucn1 on food intake and energy substrate utilization.
\end{abstract}

\section{KEYWORDS}

\section{Energy Substrate Oxidation; Food Intake; Lateral Septum; Respiratory Quotient; Urocortin}

\section{Introduction}

The mammalian peptide urocortin 1 (Ucn1) shares a 45\% sequence identity with corticotropin-releasing hormone (CRH) and binds with high affinity to CRH1 and CRH2 receptor subtypes [1-5]. Ucn1, with its 40 amino acid sequence, is expressed in many areas of the rat nervous system, including but not limited to the Edinger-Westphal nucleus, hypothalamus, brainstem, and pituitary [24]. Along with urocortin 2 (Ucn2) and urocortin 3 (Ucn3), Ucn1 has been implicated in the control of stress and anxiety, specifically when injected into the basolateral amygdala and associated limbic structures [6-12]. Indeed the central distribution of the urocortins, as well as their discrete action and affinity for CRH receptor subtypes, suggests the peptides act in a localized manner as important regulators in the neurohormonal control of stress $[9,13,14]$.

All three Ucn peptides have been associated with adaptive changes in energy metabolism including lipid

${ }^{*}$ Corresponding author. mobilization. For example, Ucn1 dose-dependently inhibits food intake and lowers the respiratory exchange ratio (RER), a measure of metabolic function [15-17]. The impact on RER is observed when injected directly into hypothalamic nuclei. RER is utilized to assess substrate oxidation via indirect calorimetry and reflects respiratory quotient, the volume of carbon dioxide produced divided by the volume of oxygen consumed at the cellular level [18]. With respect to food intake, the anorexigenic effects of Ucn1 have been observed after injection into the supraoptic nucleus and the paraventricular nucleus (PVN) of the hypothalamus $[16,17,19]$. The latter region is extensively implicated in homeostatic function [20-22]. The dorsal raphe nucleus appears to be similarly responsive to urocortin as microinjection of Ucn1 into this brain region elicits significant reductions in the amount of food consumed and in body weight gain [23]. These findings are in agreement with other work showing that ventricular administration of Ucn1 induces alterations in metabolic control, and in particular, via thermoregulatory mechanisms [24]. In addition, gastric emptying or the motil- 
ity of the gastrointestinal tract may also be affected by central urocortin transmission [25]. While species differences exist, the overall consistent finding is that Ucn1 is a catabolic signal $[15,16]$.

In the present study we examined the impact of Ucn1 on eating and substrate oxidation following direct injections into the lateral septum. Given an earlier report suggesting that lateral septal Ucn1 is anorexigenic in foodrestricted rodents [26], we hypothesized that Ucn1 would suppress spontaneous eating occurring during the nocturnal period. We further hypothesized that the peptide would reduce measures of RER, consistent with its action in the PVN, thereby promoting enhanced lipid oxidation. Finally, we examined eating and RER effects in both male and female rats, as sex-dependent responses have not yet been investigated.

\section{Materials and Methods}

\subsection{Animals}

Adult female and male Sprague-Dawley rats $(\mathrm{N}=32$, Harlan) were used in both experiments. Animals were individually housed post-surgery in polypropylene cages with free access to food and water. The colony room was maintained on a $12 \mathrm{~h} \mathrm{light/dark} \mathrm{cycle} \mathrm{(lights} \mathrm{off} \mathrm{at} 1400 \mathrm{~h}$ ) and with an ambient temperature of $22^{\circ} \mathrm{C} \pm 2^{\circ} \mathrm{C}$. Testing was conducted during the active nocturnal period. Experiments were executed in accordance with the Institutional Animal Care and Use Committee guidelines of Reed College.

\subsection{Stereotaxic Surgery}

Animals were anesthetized with pentobarbital sodium (50 mg/kg IP) and then placed into a Kopf stereotaxic apparatus with the incisor bar set to $3.5 \mathrm{~mm}$ below the interaural line. Stainless steel guide cannulae (22 gauge; Plastics One) were unilaterally implanted $1 \mathrm{~mm}$ dorsal to the lateral septum. Stereotaxic coordinates relative to bregma were anterior $0.7 \mathrm{~mm}$, lateral $\pm 0.4 \mathrm{~mm}$, and ventral $4.2 \mathrm{~mm}$ [27]. Each cannula was fitted with a stainless steel inner stylet. Behavioral and metabolic testing began following a postoperative recovery period of 14 days.

\subsection{Apparatus}

An OXYMAX Lab Animal Monitoring System measured oxygen $\left(\mathrm{O}_{2}\right)$ consumption and carbon dioxide $\left(\mathrm{CO}_{2}\right)$ production via open-circuit calorimetry (Columbus Instruments). Detectors measured $\mathrm{O}_{2}$ and $\mathrm{CO}_{2}$ sequentially across each test chamber. Concentrations of the gases were recorded in $\mathrm{ml} / \mathrm{kg}$ body weight $/ \mathrm{min}$. The analysers were calibrated prior to each test using primary gas standards of high purity (Praxair). RER was calculated as the volume of $\mathrm{CO}_{2}$ produced $\left(\mathrm{VCO}_{2}\right)$ divided by the volume of $\mathrm{O}_{2}$ consumed $\left(\mathrm{VO}_{2}\right)$, providing an estimate of respiratory quotient. Lower RER values in the range of 0.7 0.85 are indicative of fat metabolism whereas higher values represent a shift in favour of carbohydrate oxidation $[16,18]$.

\subsection{Experimental Design}

In feeding tests, groups of female $(n=8)$ and male $(n=8)$ rats were implanted with cannula aimed at the lateral septum. Ucn1 was dissolved in sterile isotonic saline and injected unilaterally into the lateral septum with a 28-gauge microinjector (Plastics One). The injector extended $1 \mathrm{~mm}$ beyond the end of the indwelling cannula. A total volume of $0.2 \mu \mathrm{l}$ was delivered over a two-minute period with the injector left in place for an additional two minutes to permit the diffusion of the peptide into brain tissue. Doses of Ucn1 ranged from $10-100$ pmol and were injected at the start of the nocturnal period. Under control conditions, rats received saline vehicle treatment. Food intakes were measured at 2 and $4 \mathrm{~h}$ postinjection. All rats received each dose of peptide administered in a randomized order. At least 4 days separated successive testing. Similar injection procedures were followed for metabolic testing using separate groups of female $(n=8)$ and male $(n=8)$ rats. Again, Ucn1 was injected at dark onset at doses of $10-100$ pmol. RER was measured over a 4-h period and testing began immediately after the rats were placed into the apparatus. Food and water were not available during this time in order to eliminate any alteration of RER measures associated with spontaneous energy consumption.

\subsection{Statistical Analyses and Histology}

Data were analyzed using two-way (treatment $\times$ time) analyses of variance for repeated measures followed by post hoc Tukey tests to probe group comparisons. The criterion for statistical significance was $p<0.05$. Guide cannula placements were confirmed through histological examination. Tissue sections were examined by light microscopy and viewed relative to the stereotaxic atlas of Paxinos and Watson [27]. All rats reported here were observed to have injector tracks extending into the lateral septum.

\section{Results}

As shown in Figure 1, Ucn1 administration suppressed food consumption at 2-h and 4-h intake measures in female rats $(F(2,14)=5.8, p<0.01)$. The effect was dosedependent with each of the two doses producing reliable reductions in intake. Similarly, as illustrated in Figure 2, these same doses of Ucn1 decreased food intake in male rats at both time points $(\mathrm{F}(2,14)=10.7, p<0.002)$. Again, the effect was dose-dependent. In metabolic test- 


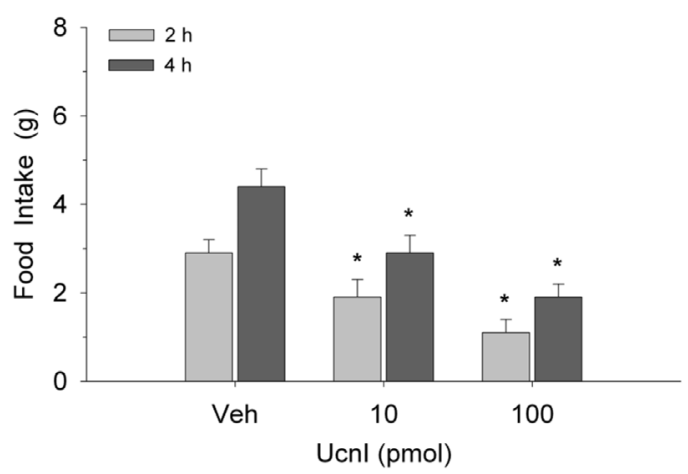

Figure 1. Ucn1 injection into the lateral septum suppressed food intake in female rats $(n=8)$ at 2 and $4 \mathrm{~h}$ postinjection. Values represent mean intakes \pm S.E.M. ${ }^{*} p<0.05$ compared to vehicle (Veh).

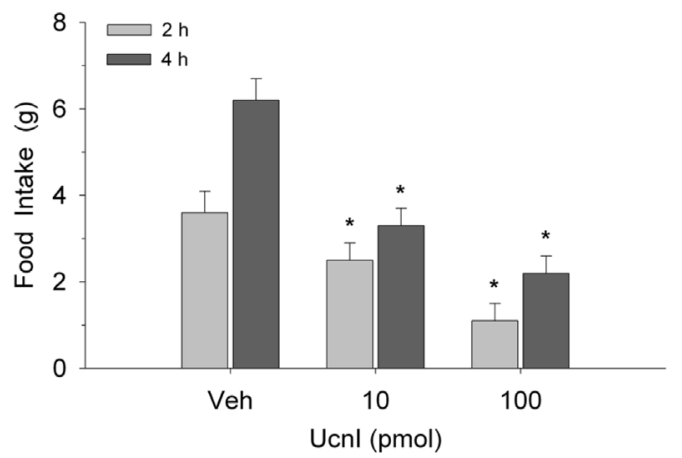

Figure 2. Microinjection of Ucn1 into the lateral septum decreased food intake in male rats $(n=8)$ at 2 and $4 \mathrm{~h}$ postinjection. Values represent mean intakes \pm S.E.M. ${ }^{*} p<$ 0.05 compared to vehicle (Veh).

ing, Ucn1 treatment lowered RER values in female $(\mathrm{F}(48,336)=34.1, p<0.003$; Figure 3) and male $(\mathrm{F}(48,336)=93.6, p<0.0001$; Figure 4$)$ rodents. Significant reductions in RER were evident within 40 min of injections and were sustained over the remainder of the 4-h test period. While both doses of Ucn1 lowered RER, the higher dose of $100 \mathrm{pmol}$ elicited a maximal impact on this metabolic measure.

\section{Discussion}

In the present study direct lateral septum administration of Ucn1 suppressed food intake in free-feeding male and female rats. Ucn 1 also lowered RER indicating an action specific to lipid oxidation. Since the change in RER occurred under test conditions where food was not available, the observed alteration in substrate utilization is arguably independent of the peptide's anorexigenic effect. Our findings are consistent with other research examining the impact of hypothalamic PVN Ucn1 treatment in male rodents [15-17]. In these studies PVN Ucn1 promoted lipid utilization $[15,16]$ similar to the effect observed here. While the precise circuitry through which

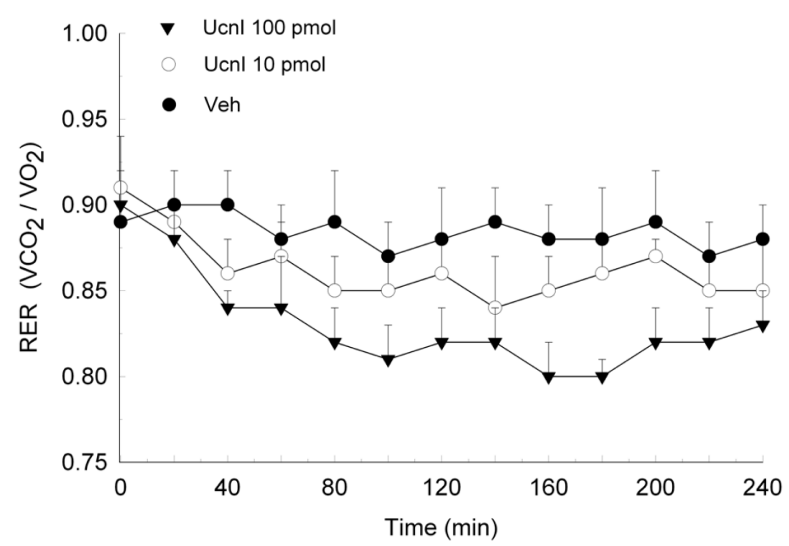

Figure 3. Lateral septum administration of Ucn1 significantly lowered the respiratory exchange ratio (RER) of female rodents $(n=8)$ within 40 min of treatment and the suppression of RER was maintained over the remainder of the 4-h test. The decrease in RER is consistent with enhanced oxidation of lipid. Values are represented as mean \pm S.E.M. ${ }^{*} p<0.05$ compared to vehicle (Veh).

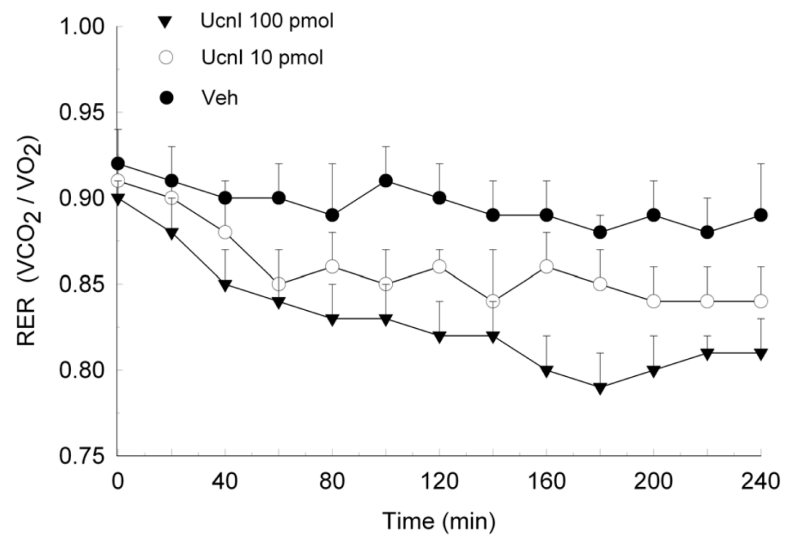

Figure 4. Administration of Ucn1 into the lateral septum of male rats $(n=8)$ reliably decreased the respiratory exchange ratio (RER) within $40 \mathrm{~min}$ of injection. The reduction of RER was maintained for the remainder of the 4-h postinjection period. Such a reduction is consistent with enhanced lipid oxidation. Values are represented as mean \pm S.E.M. ${ }^{*} p<0.05$ compared to vehicle (Veh).

septal Ucn1 alters metabolic activity is not fully understood, earlier work has implicated orexin A signaling. Ucn1 injections into the lateral septum have been shown to reduce the feeding effect of orexin A administered into the lateral hypothalamus and pretreatment with the $\mathrm{CRH}$ receptor antagonist, alpha-helical CRH, blocks the inhibitory effect of Ucn1 on orexin A-stimulated eating [26]. Moreover, high levels of Ucn1 peptide and expression of $\mathrm{CRH}$ type 2 receptors have been reported in the lateral septum and this brain region has anatomical connections with the hypothalamus [28-30]. Interestingly the anxiogenic or stress response elicited by Ucn1, a welldocumented finding $[6,12,31]$, is also partly mediated by orexin A transmission [32]. 
Another possibility is that Ucn1 inhibits eating through an interaction with central serotonin (5-HT). One previous report suggests that the anorexigenic effect of lateral septal Ucn1 is mediated via the activation of $5-\mathrm{HT}_{2 \mathrm{c}}$ receptors [33]. Hypothalamic serotonergic mechanisms have been extensively implicated in energy metabolism. For example, exogenous PVN serotonin administration suppresses the effects of ghrelin and neuropeptide $\mathrm{Y}$ (NPY) on eating and energy metabolism $[34,35]$. The inhibitory effect of 5-HT appears to be mediated through 5- $\mathrm{HT}_{2 \mathrm{a} / 2 \mathrm{c}}$ receptors since PVN injection of the 5- $\mathrm{HT}_{2 \mathrm{a} / 2 \mathrm{c}}$ agonist DOI attenuates the effects of either peptide on food intake and substrate oxidation. Both orexigenic peptides have been reported to increase RER resulting in enhanced carbohydrate oxidation and the preservation of lipid stores $[18,32,35,36]$. The action of DOI is in turn reversed by pretreatment with ketanserin or spiperone [35].

The effects of Ucn1 on food intake and energy metabolism are in direct contrast to those observed following NPY or ghrelin treatment. Again, hypothalamic NPY and ghrelin are potently orexigenic and both peptides elicit increases in RER, contrasting with the reduction in food intake elicited by Ucn 1 and the robust decreases in RER $[18,35,36]$. It is interesting to note that similar to PVN 5-HT, local infusion of Ucn1 suppresses the eating and RER effects of either NPY or ghrelin [15]. Additionally, ventral tegmental ghrelin injection has been reported to alter ethanol consumption [37] and recent research has confirmed a positive correlation between increased ethanol intake and Ucn1 levels in the Edinger-Westphal nucleus where urocortinergic neurons project to the lateral septum [38-40]. Such findings are consistent with emerging evidence implicating ghrelin and Ucn1 in rewardrelated signaling of the mesotelencephalic system [41, 42].

While previous reports have implicated urocortin-related peptides in the regulation of energy homeostasis, both Ucn1 and CRH have been shown to act centrally to alter energy balance and inhibit food intake in various models of hyperphagia, including NPY and ghrelin-stimulated eating as described above $[15,18,43]$. These effects are in addition to other evidence showing that urocortins and CRH contribute to the integration of autonomic, neuroendocrine and behavioral responses to stress and aversive stimuli [44,45]. Again, Ucn1 binds with high affinity to CRH receptors and decreases food intake in food-deprived and free-feeding animals $[3,15,26]$. Our present results confirm however that the anorexigenic and metabolic responses of Ucn 1 are not limited to hypothalamic neurons but that such effects are mediated, at least in part, via the lateral septum. Overall, these findings are in agreement with other work showing that Ucn1 suppresses appetite through an action on CRH receptors, which is independent of adrenocorticotropin function [44]. Given that CRH type 2 receptors are expressed in high concentrations within the PVN and lateral septum [1], this suggests that the effects of Ucn1 on eating and energy metabolism, observed in the current study, are likely mediated by local type 2 receptors.

\section{Conclusion}

In summary, microinjection of Ucn1 into the lateral septum suppresses food intake and decreases the respiratory exchange ratio of both female and male rodents. These findings are consistent with evidence from hypothalamic mapping studies [15-17] demonstrating that Ucn1 exerts control over energy metabolism by inhibiting food intake and promoting lipid, but not carbohydrate, substrate oxidation. Our findings further suggest that the lateral septal region is critically involved in Ucn1 homeostatic control mechanisms.

\section{Acknowledgements}

Supported by a Reed College A.V. Davis Research Initiative Grant.

\section{REFERENCES}

[1] R. L. Hauger, V. Risbrough, O. Brauns and F. M. Dautzenberg, "Corticotropin Releasing Factor (CRF) Receptor Signaling in the Central Nervous System: New Molecular Targets," CNS and Neurological DisordersDrug Targets, Vol. 5, No. 4, 2006, pp. 453-479. http://dx.doi.org/10.2174/187152706777950684

[2] L. A. P. Vasconcelos, C. Donaldson, L. V. Sita, C. A. Casatti, C. F. P. Lotfi, L. Wang, M. Cadinouche, L. Frigo, C. Elias, D. Lovejoy and J. Bittencourt, "Urocortin in the Central Nervous System of a Primate (Cebus apella): Sequencing, Immunohistochemical and Hybridization Histochemical Characterization,” Journal of Comparative Neurology, Vol. 463, No. 2, 2003, pp. 157-175. http://dx.doi.org/10.1002/cne.10742

[3] J. Vaughan, C. Donaldson, J. Bittencourt, M. H. Perrin, K. Lewis, S. Sutton, R. Can, A. V. Turnbull, D. Lovejoy, C. Rivier, J. Rivier, P. E. Sawchenko and W. Vale, "Urocortin, A Mammalian Neuropeptide Related to Fish Urotensin 1 and to Corticotropin-Releasing Factor," Nature, Vol. 378, No. 6554, 1995, pp. 287-292.

http://dx.doi.org/10.1038/378287a0

[4] L. Yang, P. Tovote, M. Rayner, J. Kockskamper, B. Pieske and J. Spiess, "Corticotropin-Releasing Factor Receptors and Urocortins, Links between the Brain and the Heart," European Journal of Pharmacology, Vol. 632, No. 1, 2010, pp. 1-6. http://dx.doi.org/10.1016/j.ejphar.2010.01.027

[5] P. Weihong and A. J. Kastin, "Urocortin and the Brain," Progress in Neurobiology, Vol. 84, No. 2, 2007, pp. 148156.

[6] P. J. Currie, L. M. Schuette, S. E. R. Wauson, W. N. Voss 
and M. J. Angeles, “Activation of Urocortin 1 and Ghrelin Signaling in the Basolateral Amygdala Induces Anxiogenesis,” NeuroReport, Vol. 25, No. 1, 2013, pp. 60s$64 s$.

[7] A. Neufeld-Cohen, M. M. Tsoory, A. K. Evans, D. Getselter, S. Gil and C. A. Lowry, "A Triple Urocortin Knockout Mouse Model Reveals an Essential Role for Urocortins in Stress Recovery," Proceedings of the National Academy of Sciences of the United States of America, Vol. 107, No. 44, 2010, pp. 19020-19025. http://dx.doi.org/10.1073/pnas.1013761107

[8] A. Skórzewska, A. Bidziński, M. Lehner, D. Turzyńska, A. Sobolewska, A. Wisłowska-Stanek, P. Maciejak, J. Szyndler and A. Płaźnik, "The Localization of Brain Sites of Anxiogenic-Like Effects of Urocortin-2,” Neuropeptides, Vol. 45, No. 1, 2010, pp. 83-92.

http://dx.doi.org/10.1016/j.npep.2010.11.003

[9] B. Ray, D. L. Gaskins, T. J. Sajdyk, J. P. Spence, S. D. Fitz, A. Shekhar and D. K. Lahiri, "Restraint Stress and Repeated Corticotropin-Releasing Factor Receptor Activation in the Amygdala Both Increase Amyloid- $\beta$ Precursor Protein and Amyloid- $\beta$ Peptide but Have Divergent Effects on Brain-Derived Neurotrophic Factor and Pre-Synaptic Proteins in the Prefrontal Cortex of Rats," Neuroscience, Vol. 184, 2011, pp. 139-150. http://dx.doi.org/10.1016/j.neuroscience.2011.03.067

[10] C. Hansson, D. Haage, M. Taube, E. Egecioglu, N. Salome and S. L. Dickson, "Central Administration of Ghrelin Alters Emotional Responses in Rats: Behavioural, Electrophysiological, and Molecular Evidence," Neuroscience, Vol. 180, 2011, pp. 201-211. http://dx.doi.org/10.1016/j.neuroscience.2011.02.002

[11] D. R. Gehlert, A. Shekhar, S. M. Hipskind, P. A. Zink, S. L. Gackenheimer, J. Shaw, S. D. Fitz and T. J. Sajdyk, "Stress and Central Urocortin Increase Anxiety-Like Behavior in the Social Interaction Test Via the CRF1 Receptor," European Journal of Pharmacology, Vol. 509, No. 2, 2005, pp. 145-153.

http://dx.doi.org/10.1016/j.ejphar.2004.12.030

[12] L. M. Dono and P. J. Currie, "The Cannabinoid Receptor $\mathrm{CB}_{1}$ Inverse Agonist AM251 Potentiates the Anxiogenic Activity of Urocortin 1 in the Basolateral Amygdala," Neuropharmacology, Vol. 62, No. 1, 2012, pp. 192-199. http://dx.doi.org/10.1016/j.neuropharm.2011.06.019

[13] Y. Zhao, G. R. Valdez, É. M. Fekete, J. E. Rivier, W. W. Vale, K. C. Rice, F. Weiss and E. P. Zorrilla, "SubtypeSelective Corticotropin-Releasing Factor Receptor Agonists Exert Contrasting, but Not Opposite, Effects on Anxiety-Related Behavior in Rats," The Journal of Pharmacology and Experimental Therapeutics, Vol. 348, No. 3, 2007, pp. 846-854. http://dx.doi.org/10.1124/jpet.107.123208

[14] Z. Bagosi, K. Csabafi, M. Palotai, M. Jászberényi, I. Földesi, J. Gardi, G. Szabó and G. Telegdy, "The Interaction of Urocortin II and Urocortin III with Amygdalar and Hypothalamic Corticotropin-Releasing Factor (CRF)Reflections on the Regulation of the Hypothalamic-Pituitary-Adrenal (HPA) Axis,” Neuropeptides, Vol. 47, No. 5, 2013, pp. 333-338. http://dx.doi.org/10.1016/j.npep.2013.07.001
[15] P. J. Currie, C. D. Coiro, R. Duenas, J. L. Guss, A. Mirza and N. Tal, "Urocortin I Inhibits the Effects of Ghrelin and Neuropeptide Y on Feeding and Energy Substrate Utilization,” Brain Research, Vol. 1385, 2011, pp. 127134. http://dx.doi.org/10.1016/j.brainres.2011.01.114

[16] P. J. Currie, D. V. Coscina, C. Bishop, C. D. Coiro, G. F. Koob, J. Rivier and W. Vale, "Hypothalamic Paraventricular Nucleus Injections of Urocortin Alter Food Intake and Respiratory Quotient,” Brain Research, Vol. 916, No. 1, 2001, pp. 222-228. http://dx.doi.org/10.1016/S0006-8993(01)02851-7

[17] C. Wang, M. A. Mullet, M. J. Glass, C. J. Billington, A. S. Levine and C. M. Kotz, "Feeding Inhibition by Urocortin in the Rat Hypothalamic Paraventricular Nucleus," The American Journal of Physiology-Regulatory, Integrative, and Comparative Physiology, Vol. 280, No. 2, 2011, pp. R473-R480.

[18] P. J. Currie, "Integration of Hypothalamic Feeding and Metabolic Signals: Focus on Neuropeptide Y,” Appetite, Vol. 41, No. 3, 2003, pp. 335-337. http://dx.doi.org/10.1016/j.appet.2003.08.011

[19] A. Fatima, S. Andrabi, G. Wolf, M. Engelmann and M. G. Spina, "Urocortin 1 Administered into the Hypothalamic Supraoptic Nucleus Inhibits Food Intake in Freely Fed and Food-Deprived Rats," Amino Acids, Vol. 44, No. 3, 2013, pp. 879-885. http://dx.doi.org/10.1007/s00726-012-1415-7

[20] C. D. Chapman, L. M. Dono, M. C. French, Z. Y. Weinberg, L. M. Schuette and P. J. Currie, "Paraventricular Nucleus Anandamide Alters Eating and Substrate Oxidation,” NeuroReport, Vol. 23, No. 7, 2012, pp. 425429.

[21] J. Maniam and M. J. Morris, "The Link between Stress and Feeding Behavior,” Neuropharmacology, Vol. 63, No. 1, 2012, pp. 97-110. http://dx.doi.org/10.1016/j.neuropharm.2012.04.017

[22] P. J. Currie, R. Khelemsky, E. M. Rigsbee, L. M. Dono, C. D. Coiro, C. D. Chapman and K. Hinchcliff, "Ghrelin Is an Orexigenic Peptide and Elicits Anxiety-Like Behaviors Following Administration into Discrete Regions of the Hypothalamus,” Behavioral Brain Research, Vol. 226, No. 1, 2012, pp. 96-105. http://dx.doi.org/10.1016/j.bbr.2011.08.037

[23] A. Z. Weitemier and A. E. Ryabinin, "Urocortin 1 in the DorsalRaphe Regulates Food and Fluid Consumption but Not Ethanol Preference in C57BL/6J Mice," Neuroscience, Vol. 137, No. 4, 2006, pp. 1439-1445. http://dx.doi.org/10.1016/j.neuroscience.2005.10.021

[24] M. J. Figueirdo, A. S. Fabricio, R. R. Machado, M. C. Melo, D. M. Soares and G. E. Souza, "Increase of Core Temperature Induced by Corticotropin-Releasing Factor and Urocortin: A Comparative Study," Regulatory Peptides, Vol. 165, No. 2, 2010, pp. 191-199. http://dx.doi.org/10.1016/j.regpep.2010.07.167

[25] L. Wang, V. Martinez, J. Rivier and Y. Tache, "Peripheral Urocortin Inhibits Gastric Emptying and Food Intake in Mice: Differential Role of CRF Receptor 2,” American Journal of Physiology-Regulatory, Integrative, and Comparative Physiology, Vol. 281, No. 5, 2001, pp. 14011410. 
[26] C. Wang and C. M. Kotz, "Urocortin in the Lateral Septal Area Modulates Feeding Induced by Orexin A in the Lateral Hypothalamus," American Journal of Physiology, Vol. 2832, No. 2, 2002, pp. R358-R367.

[27] G. Paxinos and C. Watson, "The Rat Brain in Stereotaxic Coordinates,” Academic Press, New York, 2007.

[28] A. V. da Silva, K. R. Torres, C. A. Haemmerle, I. C. Céspedes and J. C. Bittencourt, "The Edinger-Westphal Nucleus II: Hypothalamic Afferents in the Rat,” Journal of Chemical Neuroanatomy, Vol. 54, 2013, pp. 5-19. http://dx.doi.org/10.1016/j.jchemneu.2013.04.001

[29] E. M. Fekete and E. P. Zorrilla, "Physiology, Pharmacology, and Therapeutic Relevance of Urocortins in Mammals: Ancient CRF Paralogs," Frontiers in Neuroendocrinology, Vol. 28, No. 1, 2006, pp. 1-27. http://dx.doi.org/10.1016/j.yfrne.2006.09.002

[30] B. K. Bachtell, A. Z. Weitemier, A. Galvan-Rosas, N. O. Tsivkovskaia, F. O. Risinger, T. J. Philips, N. J. Grahame and A. E. Ryabinin, "The Edinger-Westphal-Lateral Septum Urocortin Pathway and Its Relationship to Alcohol Consumption,” Journal of Neuroscience, Vol. 23, No. 6, 2003, pp. 2477-2487.

[31] T. Kozicz, L. Sterrenburg and L. Xu, "Does Midbrain Urocortin Matter? A 15-Year Journey from Stress (Mal)Adaptation to Energy Metabolism," Stress, Vol. 14, No. 4, 2011, pp. 376-383.

[32] T. L. Emmerzaal, R. H. Doelen, E. W. Roubos and T. Kozicz, "Orexinergic Innervation of Urocortin1 and Cocaine and Amphetamine Regulated Transcript Neurons in the Midbrain Centrally Projecting Edinger-Westphal Nucleus," Journal of Chemical Neuroanatomy, Vol. 54, 2013, pp. 34-41. http://dx.doi.org/10.1016/j.jchemneu.2013.07.004

[33] Y. Harada, K. Takayama, S. Ro, M. Ochiai, M. Noguchi, S. Iizuka, T. Hattori and K. Yakabi, "Urocortin1-Induced Anorexia Is Regulated by Activation of the Serotonin 2C Receptor in the Brain,” Peptides, Vol. 51, 2013, pp. 139144. http://dx.doi.org/10.1016/j.peptides.2013.11.009

[34] P. J. Currie, C. S. John, M. L. Nicholson, C. D. Chapman and K. E. Loera, "Hypothalamic Paraventricular 5-Hydroxytryptamine Inhibits the Effects of Ghrelin on Eating and Energy Substrate Utilization," Pharmacology, Biochemistry \& Behavior, Vol. 97, No. 1, 2010, pp. 152-155. http://dx.doi.org/10.1016/j.pbb.2010.05.027

[35] P. J. Currie, C. D. Coiro, T. Niyomchai, A. Lira and F. Farahmand, "Hypothalamic Paraventricular 5-Hydroxytryptamine: Receptor Specific Inhibition of NPY-Stimulated Eating and Energy Metabolism," Pharmacology, Biochemistry \& Behavior, Vol. 71, No. 4, 2002, pp. 709716. http://dx.doi.org/10.1016/S0091-3057(01)00671-2

[36] P. J. Currie, A. Mirza, R. Fuld, D. Park and J. R. Vasselli, "Ghrelin Is an Orexigenic and Metabolic Signaling Pep- tide in the Arcuate and Paraventricular Nuclei,” American Journal of Physiology, Vol. 289, No. 2, 2005, pp. R353R358.

[37] A. I. Fimmel, S. L. Heichman, L. C. S. Cepko, J. A. Selva, E. M. Merfeld, S. A. Goldberg and P. J. Currie, "Low Dose Ghrelin Potentiates Psychostimulant-Induced Ethanol Intake,” Program No.775.10, Neuroscience Meeting Planner, Society for Neuroscience, San Diego, 2013.

[38] I. Fonareva, E. Spangler, N. Cannella, V. Sabino, P. Cottone, R. Ciccocioppo, E. P. Zorrilla and A. E. Ryabinin, "Increased Perioculomotor Urocortin 1 Immunoreactivity in Genetically Selected Alcohol Preferring Rats," Alcoholism: Clinical and Experimental Research, Vol. 33, No. 11, 2009, pp. 1956-1965. http://dx.doi.org/10.1111/j.1530-0277.2009.01033.x

[39] V. F. Turek, N. O. Tsivkovskaia, P. Hyytia, S. Harding, A. D. Lè and A. E. Ryabinin, "Urocortin 1 Expression in Five Pairs of Rat Lines Selectively Bred for Differences in Alcohol Drinking,” Psychopharmacology, Vol. 181, No. 3, 2005, pp. 511-517. http://dx.doi.org/10.1007/s00213-005-0011-x

[40] W. J. Giardino, D. L. Cocking, S. Kaur, C. L. Cunningham and A. E. Ryabinin, "Urocortin-1 within the Centrally-Projecting Edinger-Westphal Nucleus Is Critical for Ethanol Preference,” PLoS One, Vol. 6, No. 10, 2011, Article ID: e26997. http://dx.doi.org/10.1371/journal.pone.0026997

[41] L. M. Schuette, C. C. Gray and P. J. Currie, "Microinjection of Ghrelin into the Ventral Tegmental Area Potentiates Cocaine-Induced Conditioned Place Preference," Journal of Behavioral and Brain Science, Vol. 3, No. 8, 2013, pp. 576-580. http://dx.doi.org/10.4236/jbbs.2013.38060

[42] A. E. Ryabinin, D. L. Cocking and S. Kaur, "Inhibition of VTA Neurons Activating the Centrally Projecting Edinger-Westphal Nucleus: Evidence of a Stress-Reward Link?' Journal of Chemical Neuroanatomy, Vol. 54, 2013, pp. 57-61. http://dx.doi.org/10.1016/j.jchemneu.2013.05.004

[43] C. Tanaka, A. Asakawa, M. Ushikai, T. Sakoguchi, H. Amitani, H. Amitani, M. Terashi, K. Cheng, H. Chaolu, N. Nakamura and A. Inui, "Comparison of the Anorexigenic Activity of CRF Family Peptides," Biochemical and Biophysical Research Communications, Vol. 390, No. 3, 2009, pp. 887-891. http://dx.doi.org/10.1016/j.bbrc.2009.10.069

[44] W. Pan and A. J. Kastin, "Urocortin and the Brain," Progress in Neurobiology, Vol. 84, No. 2, 2008, pp. 148-156. http://dx.doi.org/10.1016/j.pneurobio.2007.10.008

[45] D. S. Latchman, “Urocortin,” International Journal of Biochemistry, Vol. 348, No. 8, 2002, pp. 907-910. http://dx.doi.org/10.1016/S1357-2725(02)00011-0 